\title{
TINDAKAN KOMUNIKATIF DALAM MODEL PEMBERDAYAAN WANITA PADA SEKOLAH PEREMPUAN DESA, KOTA BATU, JAWA TIMUR
}

\author{
Dhanny Septimawan Sutopo \\ Universitas Brawijaya \\ sutopo_dhaany@ub.ac.id
}

\section{ABSTRAK}

Sekolah perempuan Batu adalah sekolah informal yang bergerak dalam bidang pemberdayaan perempuan. Tujuan dari berdirinya sekolah perempuan ini juga melegitimasi tujuan dari gerakan feminisme yang menghendaki laki-laki dan perempuan memiliki akses yang sama dalam kehidupan sosialnya, seperti dalam hal pekerjaan, pendapatan, dan juga kesejahteraan. Persamaan akses tersebut dapat secara perlahan diwujudkan dengan mengikuti sekolah perempuan Kota Batu. Tulisan ini bertujuan untuk mengetahui bagaimana aplikasi tindakan komunikatif dalam pelaksanaan sekolah perempuan di Batu. Tindakan komunikatif ini mencakup proses partisipasi yang berkelajutan dari anggota komunitas, mengurangi narasi besar, aktif dalam melakukan diskusi dan dialog publik yang mengembangkan pengetahuan yang setara. Melalui penelitian kualitatif ditemukan bahwa tindakan komunikatif dalam pelaksanaan sekolah perempuan Batu menganut konsep parsitipatif dimana para peserta diperlakukan sebagai subyek sekaligus obyek dalam kegiatan ini. Spirit utama yang dibangun dalam sekolah 
perempuan ini antara lain: kesederhanaan, kemandirian, kejujuran, keadilan, kesetaraan, menolak kekerasan dan diskriminasi.

Kata kunci: Tindakan komunikatif, Pemberdayaan, Pendidikan Wanita

\section{ABSTRACT}

Sekolah Perempuan Batu is an informal school for women which is conducted in order to fulfill the main purpose of their empowerment. This purpose also legitimize the goals of feminism movement that requires men and women equality to access social life in terms of jobs, income, and welfare. This paper aims to describe the application of communicative action in the implementation of Sekolah Perempuan Batu. This communicative action includes a process of sustained participation of community member, reducing the grand narrative, active discussions and public dialogue that develops the knowledge equivalent. Through qualitative research found that communicative action in the implementation of Sekolah Perempuan Batu embrace the concept of participatory where participants are treated as subject as well as object in this activity. The main spirit built in Sekolah Perempuan Batu are: simplicity, self-reliance, honesty, fairness, equality, rejection of violence and discrimination.

Keywords: communicative action, empowerment, women's education

\section{A. Pendahuluan}

Pembedaan berbasis gender antara laki-laki dan perempuan telah lama menjadi pembicaraan yang menarik perhatian para pejuang perempuan di dunia. Masyarakat membedakan laki-laki dan perempuan sejak awal kehidupan manusia. Pembedaan antara laki-laki dan perempuan tersebut secara tidak langsung telah terjadi secara turun temurun dan perlahan telah dilegitimasi oleh masyarakat itu sendiri. Pembedaan gender dalam bentuk subordinasi 
perempuan ditemukan di Kota Batu. Subordinasi perempuan adalah penempatan perempuan yang selalu berada pada urutan kedua setelah laki-laki. Subordinasi yang dialami oleh kaum perempuan ini menyebabkan berbagai masalah yang membelenggu para perempuan. Kota Batu yang notabenenya adalah kota yang cukup besar dan sekaligus sebagai kota wisata, nyatanya juga tidak lepas dari masalah subordinasi perempuan.

Sekolah perempuan adalah sekolah untuk perempuan di pedesaan. Sekolah ini merupakan wadah perempuan desa bertukar pengetahuan dan pengalaman, menemu-kenali kebutuhan dan juga kepentingan perempuan, untuk meningkatkan kualitas hidupnya. Sekolah perempuan Kota Batu bertujuan membangun dan memperkuat kepemimpinan perempuan di pedesaan. Pengetahuan dan pengalaman yang dipertukarkan dalam sekolah ini berkaitan dengan kebutuhan perempuan yang bersifat praktis maupun strategis. Pengetahuan yang berkontribusi memenuhi kebutuhan praktis perempuan diantaranya adalah pengetahuan dan ketrampilan untuk meningkatkan pendapatan (Income) keluarga, ketrampilan tata boga, bisnis kuliner, teknologi informasi. Ada juga pengetahuan tentang keadilan dan kesetaraan gender, pengetahuan tentang parenting, pengetahuan tentang gizi (dalam hal produksi dan konsumsi makanan sehat), pengetahuan tentang sanitasi dan pola hidup bersih dan sehat; pengetahuan tentang hak-hak reproduksi perempuan, pengetahuan tentang kesehatan keluarga, bahasa Inggris, public speaking, serta kepemimpinan perempuan.

Selain pengetahuan praktis, juga diajarkan pengetahuan yang berkontribusi memenuhi kebutuhan strategis perempuan diantaranya; pengetahuan tentang hak asasi manusia; hak-hak anak; hak-hak perempuan; hak-hak kelompok minoritas; pengetahuan tentang hak-hak perempuan sebagai warga negara; pengetahuan tentang perencanaan pembangunan di tingkat lokal, nasional yang berpengaruh terhadap kehidupan perempuan. Ada juga pengetahuan tentang sistem ekonomi global dan dampaknya bagi perempuan 
pedesaan. Pengetahuan hak-hak perempuan atas pangan (sistem produksi, distribusi dan konsumsi pangan). Pengetahuan tentang pertanian yang berkelanjutan, dampak pengelolaan lingkungan hidupserta dampak perubahan iklim terhadap kehidupan perempuan. Sekolah perempuan ini diselenggarakan oleh suara perempuan desa (SPD-Rural Women's Voices) dan Karya Bunda Community (KBC Kota Batu - Jawa Timur yang sekaligus sebagai penggagas berdirinya sekolah perempuan desa tersebut. Di samping itu sekolah perempuan juga tentunya melibatkan peran dari perempuan desa yang memiliki potensi untuk menjadi penyelenggara sekolah tersebut.

Peserta sekolah perempuan adalah perempuan-perempuan di desa-desa atau kelurahan di Kota Batu Jawa Timur. Pada tahun 2013, 275 perempuan dari 4 desa menjadi peserta. Tahap ke 2 periode Januari-Juni 2014 sebanyak 135 perempuan dari 5 Desa, yaitu Desa Guunungsari (Petani Bunga, Sayur), Desa Sumberejo (Petani sayur, bunga), Desa sidomulyo (Petani Bunga, pekerja handycraft, pedagang) Desa Bulukerto (Petani, Pedagang), Kel. Sisir (Pedagang, Pekerja swasta). Peserta dari sekolah perempuan ini tidak mengenal batasan, baik dari segi pekerjaan, usia mupun latar belakang pendidikan. Setiap warga perempuan yang berada di wilayah tersebut diberikan kebebasan untuk berpartisipsi menjadi peserta sekolah perempuan. Tidak adanya batasan tersebut menjadikan perempuan desa bersemangat dan memiliki peluang untuk menjadi peserta dan dapat mengembangkan potensi yang dimiliki dengan adanya materi yang telah diberikan. Sekolah perempuan bekerjasama dengan individu maupun institusi / lembaga di dalam dan di luar Kota Batu Jawa Timur untuk menjadi narasumber/fasilitator untuk sekolah ini. Sekolah perempuan tercatat telah menjalin hubungan kerjasama dengan beberapa Lembaga yang ada di Kota Malang dan Batu sebagai narasumber diantaranya : Badan Narkotika Nasional (BNN), Omah Munir, IBI (Ikatan Bidan Indonesia), PHRI tata boga, Rias Salon dan Pondok Pesantren Tebu Ireng. Sekolah perempuan desa dilaunching atau diresmikan pada 23 Agustus 2013. Pelaksanaan program tahap 
pertama diselenggarakan pada Agustus-Desember 2013. Pendidikan tahap kedua di launching pda 28 Desember 2013, proses belajar pada Januari-Juni 2014. Tahap ke -3 di launching 11 Oktober 2014, proses belajar Oktober 2014-April 2015. Sekolah perempuan dilakukan pada minggu pertama hingga minggu ke tiga setiap bulan. Tiap minggu satu subyek/materi akan disampaikan pada peserta, baik menyangkut pengetahuan praktis maupun strategis. Waktu kegiatan dimulai pada pukul 13.00-15.00 WIB.Untuk monitoring dilakukan pada minggu terakhir tiap bulan, melalui diskusi kelompok terarah (FGD) bersama 10-15 orang peserta. Evaluasi dilakukan pada akhir program.

Artikel ini berupaya mengelaborasi program pemberdayaan perempuan "Sekolah Perempuan Desa" di Kota Batu sebagai upaya mendeskripsikan tindakan komunikatif dalam program pemberdayaan perempuan di Kota Batu. Metode kualitatif berbentuk studi kasus digunakan dalam penelitian ini untuk mencapai pemahaman mendalam terhadap isu yang diamati (Salim, 2011).

\section{B. Pembahasan}

\section{Pemberdayaan Perempuan}

Feminisme berangkat dari bagaimana peran perempuan dalam masyakarat mengalami ketimpangan. Perkembangan feminism berawal dari pandangan bahwa terjadi sebuah ketidakadilan dalam masyarakat antara laki-laki dan perempuan.Ketidakadilan tersebut terus dilegitimasi oleh masyarakat menjadi sebuah ketimpangan laki-laki dan perempuan. Konsep pemberdayaan perempuan menjadi jalan agar kelompok perempuan yang lemah dalam akses dan asset dapat lebih mandiri.Pemberdayaan masyarakat dalam ranah ini mengasumsikan bahwa pembagian kerja laki-laki dan perempuan serta upah/gaji/pendapatan dan kepemilikan faktor produksi yang tidak adil. Dalam upaya pemberdayaan ini, seorang pengembang masyarakat mampu membangun kesadaran dalam pandangan 
mereka soal budaya patriarki (kelaki-lakian) memperlihatkan bagaimana kurangnya akses perempuan, menguatkan pilihan serta memperluas hal perempuan serta berkesadaran sosial dari bahasa sehari-hari yang masih sexiest gender (Kenny, 2010).

Pemberdayaan yang dilakukan terhadap perempuan juga berangkat dari titik tolak pembagian kerja gender, perempuan diasumsikan memiliki beban ganda dalam kehidupannya.Selain memiliki tugas domestik (mengurus anak dan keperluan rumah tangga), perempuan juga bertugas mencari nafkah di luar rumah. Beban ganda tersebut kemudian masih banyak ditambah dengan budaya patriarkhi di masyarakat yang menganggap bahwa perempuan masih ditempatkan sebagai "warga negara kedua" setelah laki-laki.

Pemberdayaan perempuan adalah upaya pemampuan perempuan untuk memperoleh akses dan kontrol terhadap sumber daya, ekonomi, politik, sosial, budaya, agar perempuan dapat mengatur diri dan meningkatkan rasa percaya diri untuk mampu berperan dan berpartisipasi aktif dalam memecahkan masalah, sehingga mampu membangun kemampuan dan konsep diri (Novian, 2010). Permberdayaan perempuan di kota Batu dilakukan sebuah Non Government Organization (NGO) yaitu Suara Perempuan Desa. Mereka menginisiasi dari berdirinya Sekolah Perempuan Desa. Perempuan dituntut memiliki kepandaian, kecakapan, "melek" politik, dan memiliki ketrampilan guna membantu mendapat tambahan pendapatan keluarganya.Untuk memenuhinya, pengetahuan tersebut bisa didapatkan di Sekolah Perempuan Desa yang digagas oleh lembaga tersebut.Kebutuhan paling utama adalah mereka bisa menambah pendapatan keluarga.Karena itu, dalam sekolah informal ini, mereka bisa bertukar pengetahuan dan ketrampilan. Ada anggota yang pintar menjahit, salon atau membuat kue dapat dilakukan pertukaran pengetahuan sehingga dari hal tersebut akan digagas sebuah usaha. (Fauzi, 2013)

Suara Perempuan Desa menyelenggarakan Sekolah Perempuan 
sejak 2013 di Desa Sidomulyo dan Gunungsari.Sekolah perempuan memberikan pengetahuan praktis, pengetahuan strategis dan ketrampilan untuk meningkatkan kualitas hidup perempuan. Sebanyak 304 perempuan di Kota Batu telah mengikuti program ini sejak dimulai Agustus 2013.Kurikulum atau materi pembelajaran disesuaikan dengan kebutuhan perempuan. Kebutuhan perempuan yang sesuai akan susah didefiniskan jika seseorang tersebut tidak mempunyai kesadaran kebutuhan yang tinggi atas apa yang harus dipenuhi dalam hidupnya. Oleh karena pemberdayaan perempuan ini juga membuka partisipasi perempuan itu sendiri untuk menemukenali apa yang dibutuhkannya. Untuk merumuskan kurikulum sekolah perempuan, dilakukan serangkaian penelitian kebutuhan dan juga membuat forum diskusi bagi perempuan untuk mengidentifikasi kebutuhannya. Dengan pengetahuan strategis, mereka mampu menyuarakan isu-si keperempuanan kepada pengambil keputusan. Hasilnya mereka telah dapat meningkatkan pendapatan mereka, di sisi lain perempuan juga terbuka pengetahuan mengenai isu kesehatan reproduksi, keadilan dan kesejahteraan perempuan.

Sosialisasi tentang Sekolah Perempuan dilakukan langsung kepada kelompok perempuan dalam kegiatan keagamaan maupun birokrasi seperti PKK dan Kelompok Tahlilan. Bagan selengkapnya terlihat dalam gambar berikut:

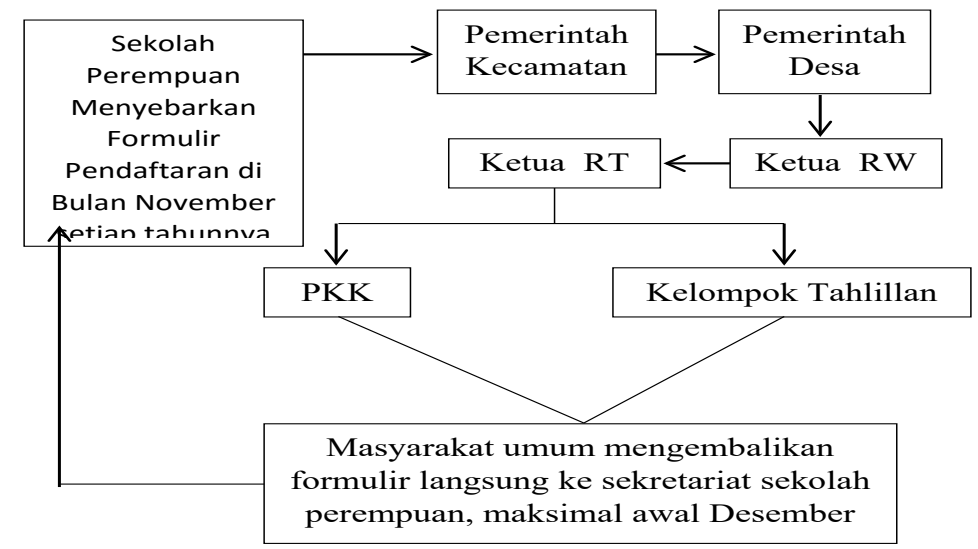

Gambar 1. Alur Pendaftaran Sekolah Perempuan

Sumber : Hasil Olahan Peneliti, 2015 
Pendaftaran sekolah perempuan Kota Batu tidaklah serumit sekolah-sekolah formal yang mensyaratkan begitu banyak persyaratan untuk kita penuhi. Syarat yang harus dipenuhi untuk mendaftar ke sekolah perempuan hanyalah mengisi formulir yang telah disebarkan. Formulir pendaftaran tersebut dibagikan pada awal periode sekolah perempuan di setiap tahunnya. Periode sekolah ini diawali pada bulan Desember dan berakhir di bulan Juni yaitu tujuh bulan pada setiap periodenya.

Berbagai program pemberdayaan yang telah berjalan dengan baik tidak luput dari interaksi yang saling memahami antara kelompok perempuan dan kelompok pemberdaya (SPD). Dalam hal ini, peneliti tertarik untuk melihat bagaimana pola dan tindakan yang komunikatif antara kelompok perempuan dan kelompok pemberdaya (SPD) dalam mewujudkan kurikulum sekolah perempuan yang partisipastif. Tindakan komunikatif diartikan sebagai tindakan yang setara dan tidak ada saling dominasi dalam usaha untuk menghubungkan individu, jaringan dan institusi dalam kepentingan kelompok, yang mendukung terciptanya sebuah demokrasi deliberatif. Oleh karena itu, dalam penelitian ini penulis melihat tindakan komunikatif yang dilakukan antara subjek pemberdaya dan objek pemberdaya dalam mengembangan kurikulum dan pengembangan program sekolah perempuan.

\section{Strategi belajar di Sekolah Perempuan Desa}

Sekolah perempuan menggunakan prinsip-prinsip feminis dan pendidikan bagi orang dewasa, antara lain :

1. Menggunakan metode partisipatif

2. Pengetahuan dan pengalaman perempuan menjadi sumber dari proses belajar.

Selain adanya strategi tersebut tentunya sekolah perempuan memiliki beberapa nilai-nilai yang menjadi landasan atau dasar dalam menjalankan program yang direncanakan, diantaranya : 
1. Kesederhanaan

Nilai kesederhanaan menjadi salah satu prinsip yng menjadi dasar dari sekolah perempun desa. Kesederhanaan diartikan bahwasannya dalam menjalankan kegiatan tentunya dijalankan dengan apa adanya. Tidak dijalankan secara berlebihan, namun lebih mengarah kepada setiap kemampuan dan kebutuhan dari anggota sekolah perempuan. Peneguhan nilai kesederhanaan ini menjadikan pengalaman tersendiri bagi para anggota, karena dengan perjuangan yang apa adanya dapat memberikan manfaat yang luar biasa yang dapat diterapkan dalam kehidupan seharihari semua anggotanya.

2. Kemandirian

Dalam pelaksanaan sekolah perempuan desa tersebut juga didasari atas nilai kemandirian. Dalam hal ini seluruh kebutuhan dari sekolah tidak bergantung kepada orang lain, baik dari segi finansial maupun dari segi sumber daya pengelolanya. Setiap kegiatan yang akan dan juga telah dilaksanakan selalu mengutamakan kemandirian, dimana para pengurus dan anggota secara bersama bergotong royong untuk melaksanakan dan mensukseskan kegiatan yang telah direncanakan. Sehingga semua kegiatan tersebut berjalan atas dasar kemandirian dari seluruh anggota.

3. Kejujuran

Kejujuran adalah dasar dari komunikasi yang efektif dan hubungan yang sehat. Ini membuktikan bahwa kejujuran sangat penting, supaya hubungan antar anggota dapat terjalin dengan harmonis. Kejujuran juga akan menciptakan komunikasi yang baik antara anggota yang satu dengan anggota yang lainnya, dan akan terciptanya rasa kepercayaan. Setiap anggota adalah kunci dari keberhasilan suatu program yang direncanakan dan dijalankan, oleh karena kejujuran menjadi sangat penting untuk ditanamkan pada setiap anggota agar kegiatan yang dilaksanakan 
sesuai dengan apa yang diharapkan.

4. Keadilan

Nilai keadilan diyakini akan memberikan kesadaran atas hak-hak perempuan yang menjadi bagian dari masyarakat. Nilai keadilan tentunya juga dapat memberikan bekal bagi para peserta sekolah perempuan untuk bersikap adil kepada orang-orang yang ada disekitarnya. Dengan demikian peserta dapat menerapkan nilai keadilan tersebut baik didalam kegiatan sekolah maupun kegiatan diluar sekolah.

5. Kesetaraan

Kesetaraan menjadi sangat penting untuk diterapkan, agar perempuan-perempuan desa dapat mendapatkan haknya tanpa adanya ketimpangan dari pihak lain. Kesetaraan akan memberikan kesempatan lebih kepada perempuan dalam mengembangkan potensinya, terutama dalam sektor publik yang selama ini perempuan seringkali berada di belakang layar.

6. Menghargai Keberagaman

Dengan adanya berbagai latar belakang diantara peserta tentunya penting untuk menerapkan nilai saling menghargai diantara keberagaman tersebut. Dengan adanya saling menghargai tentunya dapat meminimalisir adanya perselisihan antar anggota. Yang pada akhirnya nilai tersbut juga akan dapat diterapkan dalam kehidupan para perempuan di dalam masyarakat.

7. Menolak Segala Bentuk Kekerasan

Sebagai perempuan tentunya juga sangat penting untuk ditanamkan nilai penolakan terhadap adanya kekerasan. Perempuan menjadi salah satu bagian dari masyarakat yang cenderung mendapatkan resiko lebih dari adanya sikap kekerasan. Oleh karenanya penolakan terhadap kekerasan tentunya menjadi sangat penting untuk dikenalkan pada kaum perempuan.

8. Menolak Diskriminasi Atas dasar Apapun

Disamping beberapa nilai diatas penolakan atas dikriminasi 
tentunya juga sangat penting untuk diterapkan oleh perempuan. Diskriminasi seringkali menyebabkan timbulnya perselisihan dan ketimpangan sosial. Oleh karena itu anggota sekolah perempuan perlu untuk menjadikan penolakan diskriminasi menjadi dasar dalam melaksanakan kegiatan dan juga dasar bagi kehidupan sehari-hari.

\section{Tindakan Komunikatif dalam Perspektif Jurgen Harbermas}

Habermas (1987) menyatakan bahwa kolonialisasi dunia (lifeworld) melalui budaya, bahasa dan pengetahuan menyebabkan terpinggirkannya suara-suara kecil.Pengetahuan teknis yang sering dibawa oleh system (dalam hal ini pengembang komunitas) tidak cocok dikembangkan dalam upaya pengembangan komunitas secara demokratis di sebuah wilayah. Hal inilah yang menyebabkan marjinalisasi pada masyarakat karena kecenderungan masyarakat sulit berdiksusi dengan orang yang dianggap "lebih rasional" seperti para ilmuwan, elite swasta, insinyur dan sebagainya.

Pengembangan komunitas ini, dituntut untuk didukung sebuah pengetahuan yang emansipatoris/membebaskan.Dengan pengetahuan yang bersfat emansipatoris ini, diasumsikan bahwa penyelenggaraan program pengembangan komunitas dapat lebih berjalan dengan partisipatif. Pengetahuan emansipatoris menjadi irisan dari pengetahuan teknis dan pengetahuan lokal. Pengetahuan teknis dibawa oleh mereka yang memiliki seperangkat pengetahuan yang dianggap "rasional" serta pengetahuan lokal yang banyak mengarah ke pemahaman dan penafsiran dari masyarakat. Dimana hal tersebut menggerakan pada tindakan yang lebih dapat memberdayakan masyarakat.

Perspektif Habermas menjadi basis dalam bekerjanya pengembangan komunitas. Tindakan komunikatif ini mencakup proses partisipasi yang berkelanjutan dari anggota komunitas, mengurangi narasi besar, aktif dalam melakukan diskusi dan dialog 
publik yang mengembangkan pengetahuan yang setara.

Asumi yang mendasari mengapa diperlukan tindakan komunikatif dalam pengembangan komunitas adalah penduduk/ rakyat sulit berkomunikasi setara dengan elit politik, korporat yang dianggap rasional, elit politik dan korporat biasanya mendominasi pengetahuan, sehingga suara lokal tidak bisa terdengar serta pengetahuan teknis tidak cocok unutk setting demokrasi (Hustedde, 2009).

\section{Pemberdayaan Perempuan Pada Sekolah Perempuan}

Sekolah perempuan adalah sekolah informal yang bergerak dalam bidang pemberdayaan perempuan dalam menyelesaikan berbagai permasalahan perempuan sebagaimana telah diuraikan. Pemberdayaan perempuan ini hadir sebagai pergerakan atas subordinasi perempuan yang telah terjadi selama ini.Tujuan dari berdirinya sekolah perempuan ini juga melegitimasi tujuan dari gerakan feminisme yang menghendaki laki-laki dan perempuan memiliki akses yang sama dalam kehidupan sosialnya, seperti dalam hal pekerjaan, pendapatan, dan juga kesejahteraan. Persamaan akses tersebut dapat secara perlahan diwujudkan dengan mengikuti sekolah perempuan Kota Batu.

Perwujudan persamaan pada akses kehidupan sosial antara lakilaki dan perempuan memang tidak dengan mudah dapat terwujud. Dibutuhkan waktu, proses dan dukungan dari para stakeholders terkait, termasuk masyarakat itu sendiri. Melalui berbagai macam pengetahuan, pengalaman dan keterampilan yang diberikan oleh sekolah perempuan dapat menjadi bekal para perempuan untuk lebih berani dan percaya diri akan kemampuan jati dirinya sebagai perempuan dalam eksistensinya secara domestik (di rumah) dan di ruang publik. Kiprah perempuan di ranah publik tetap sinkron dengan visi kebahagiaan keluarga dan juga kebermanfaatan untuk sesama manusia yang ada di lingkungan sekitarnya. 
Tindakan Komunikatif dalam Model Pemberdayaan Wanita Pada Sekolah_

Konsep pemberdayaan sendiri adalah bertujuan untuk mengembangkan, memandirikan, menswadayakan, serta memperkuat posisi tawar menawar masyarakat lapisan bawah terhadap kekuatankekuatan penekan pada segala bidang dan sektor kehidupan (Eko, 2002). Pemberdayaan atau empowerment berarti merujuk pada memberikan daya atau kekuasaan pada masyarakat atau kelompok supaya masyarakat ataupun kelompok tersebut mampu mencapai kehidupan yang lebih baik lagi dari sebelumnya.Tujuan inilah yang mulai dirintis oleh penyelenggara sekolah perempuan Kota Batu.

Pemberdayaan perempuan yang dilakukan oleh sekolah perempuan merupakan sebuah upaya untuk mewujudkan kesetaraan peran, akses, dan juga kontrol antara perempuan dan laki-laki di semua bidang pembangunan. Kesetaraan memang sulit diwujudkanapabila diartikan sama rata tanpa sama sekali berat sebelah, tetapi yang terpenting adalah pemberian porsi yang sesuai bagi akses perempuan dalam ranah publik seperti bidang politik. Bidang politik dan juga pendidikan merupakan dua bidang yang menjadi concern utama bagi sekolah perempuan karena memang dua hal tersebutlah yang dianggap sangat tidak adil bagi kaum perempuan, padahal politik dan pendidikan merupakan dua hal yang menjadi dasar pengembangan diri bagi karir seorang manusia.

Salah satu cara mengembangkan pemberdayaan bagi perempuan adalah memberikan akses yang sama baik pada lakilaki atau perempuan pada sektor ekonomi. Materi keterampilan yang diberikan oleh sekolah perempuan juga bermuara pada pengembangan ekonomi keluarga. Melalui keterampilan yang diperoleh tersebut para peserta sekolah perempuan dapat menjual hasil olahan makanan dan kerajinan yang mereka hasilkan pada bazar tahunan menjelang hari raya yang rutin diadakan oleh sekolah perempuan.Hal tersebut juga sebagai upaya pengenalan berbagai macam usaha ekonomi kreatif yang mampu meningkatkan taraf ekonomi suatu keluarga. Menurut Muttalib (1993) upaya pemberdayaan dapat dilakukan dalam tiga hal yaitu Capacity 
building, Cultural change, dan Structural adjustment. Sekolah perempuan berusaha untuk melakukan pemberdayaan perempuan melalui ketiga aspek tersebut, walaupun yang saat ini masih terlihat intens dilakukan adalah pengembangan perempuan melalui capacity building saja. Berikut upaya pemberdayaan yang telah dilakukan oleh sekolah perempuan yaitu :

1. Capacity Building, yaitu upaya membangun kapasitas perempuan dengan peningkatan pengetahuan, keterampilan dan pengalamannya. Hal inilah yang begitu intens dilakukan oleh sekolah perempuan. Melalui pemberian materi pengetahuan dan keterampilan yang dilakukan setiap minggunya, secara langsung berdampak positif terhadap pengembangan diri dari para perempuan itu sendiri. Mereka lebih merasa percaya diri untuk tampil di depan publik menunjukkan kemampuannya sebagai perempuan. Dengan mengikuti sekolah perempuan juga mampu menambah pengalaman para perempuan, apalagi ketika mereka menjadi delegasi sekolah perempuan untuk menghadiri suatu acara yang bersifat publik. Kemudian kepanitiaan pada acara seperti "Bazar" juga memberikan pengalaman tersendiri bagi para perempuan untuk belajar mengorganisasi suatu kegiatan. Hal tersebut sesuai dengan pernyataan dari Ibu Anta, yaitu sebagai berikut :

"Ikut sekolah perempuan manfaatnya banyak, bisa untuk nambah ilmu, pengetahuan, pengalaman, nambah teman juga. Pokoknya bisa mengembangankan diri kita sebagai perempuan karena kita bisa punya pengetahuan yang berkualitas"(Hasil FGD tanggal 03 Oktober 2015, pukul 14.00 - 15.30)

2. Cultural change, yaitu dengan melakukan perubahan budaya dengan lebih adil terhadap perempuan. Hal ini masih begitu sulit dilakukan oleh sekolah perempuan karena notabenenya merubah suatu budaya tidak semudah membalikkan telapak tangan. Apalagi masyarakat Indonesia sudah terbiasa dengan budaya patriarki yang tanpa sadar telah mengakar dan mendarah daging 
pada benak masyarakat. Perubahan budaya hanya terjadi apabila masyarakat serempak melakukan legitimasi terhadap perubahan tersebut. Untuk itu sekolah perempuan hanya bisa berupaya menunjukkan eksistensi keberadaan dan kemampuan perempuan kepada masyarakat dengan tujuan supaya secara perlahan masyarakat menjadi sadar akan pentingnya kiprah perempuan di ranah publik. Hal tersebut sesuai dengan pernyataan dari Ibu Hana, yaitu sebagai berikut :

"Wah kalau untuk membuat semua orang pro dengan sekolab perempuan itu yah susah mbak, yo akeh mbak orang-orang yang masih nganggap sebelah mata tentangsekolah perempuan yang bagi mereka itu nggak penting." Yah kita biasa aja nanggapinya, terus tunjukkan eksistensi dan manfaat ikut sekolah perempuan aja, semoga dengan begitu nantinya mereka bisa sadar bahwa sekolah bagi perempuan itu penting." (Hasil wawancara tanggal 26 September 2015, pukul 10.30 - 13.00)

3. Structural adjustment, yaitu penyesuaian struktural yang memihak dapat berupa kebijakan, peraturan ataupun sistem penganggaran pembangunan yang pro terhadap gender.Hal ini juga masih sulit dilakukan oleh sekolah perempuan tanpa adanya dukungan dari berbagai pihak terkait khususnya pemerintah selaku pembuat dari peraturan ataupun sistem penganggaran pembangunan. Akan tetapi hasil nyata yang telah berhasil dilakukan oleh sekolah perempuan adalah memberikan kesadaran bagi perempuan untuk meningkatkan partisipasi mereka dalam politik. Sekolah perempuan telah mengajarkan bagaimana seharusnya para perempuan berpartisipasi dalam Musrenbang, walaupun pada akhirnya peningkatan partisipasi perempuan dalam politik "Musrenbang" adalah tergantung pada kebijakan pemerintah, tetapi setidaknya perempuan dapat menyerukan kepada pemerintah untuk memberikan porsi yang sama kepada para perempuan dalam hal partisipasi politik "Musrenbang". Harapan kedepan perempuan bukan hanya menjadi bumbu 
pelengkap bagi terpenuhinya syarat kuota minimal kehadiran perempuan dalam partisipasi politik. Hal ini sesuai dengan pernyataan dari Ibu Rina yaitu sebagai berikut :

"Kebetulan kemarin itu kita ada kerjasama dengan puskapel UI, mereka memberi banyak materi tentang Musrenbang, sehingga perempuan bisa tahu seharusnya peran mereka itu apa dalam musrenbang, kan selama ini kita sangat jarang dilibatkan dalam musrenbang mbak, palingan jadi pelengkap tok heheheh." (Hasil wawancara tanggal 26 September 2015, pukul 10.30 - 13.00)

Pemberdayaan perempuan di Indonesia secara kasat mata memang telah menghasilkan suatu proses peningkatan yang sifnifikan dalam berbagai hal. Seperti pada peningkatan kondisi, derajat, dan kualitas hidup perempuan di banyak bidang, seperti pendidikan, ketenagakerjaan, ekonomi dan kesehatan(Daulay, 2006). Namun pemberdayaan ini relatif hanya terjadi pada daerah perkotaan dan tidak berimpas pada kondisi perempuan di pedesaan, ataupun daerah-daerah peri urban, seperti halnya Kota Batu. Secara fisik Kota Batu memang merupakan satu Kota Besar, namun secara sosial masih merupakan peralihan dari perdesaan ke daerah perkotaan (Peri urban). Hal inilah yang menjadikan semangat untuk memperoleh pendidikan dan partisipasi publik bagi perempuan di Kota Batu masih dikatakan sangat kurang, dikarenakan dari tiga upaya pemberdayaan perempuan yang telah disebutkan sebelumnya, hanya satu hal yang secara real dan terlihat telah dilaksanakan dengan baik oleh pengurus sekolah perempuan, yaitu upaya pengembangan diri bagi para perempuan dalam bidang capacity building.

\section{Simpulan}

Penyelenggaran Sekolah Perempuan Desa Kota Batu menerapkan rasionalitas tindakan komunikatif. Rasionalitas tersebut dapat dilihat dari azas kebebasan dan partisipasi dalam setiap penyelenggaraan sekolah perempuan. Peserta sekolah mendapat hak untuk dapat menentukan materi ajar sesuai kebutuhan. Pengurus 
sekolah mengetahui kebutuhan peserta dikarenakan pengurus juga menjadi peserta sekolah.Terdapat dialog komunikatif antara aktor pemberdaya dan target pemberdaya. Pengelola dan peserta sekolah perempuan menggunakan prinsip deliberatif dimana tiap orang dapat mempengaruhi hasil dalam setiap keputusan di sekolah. Sekolah perempuan mengkombinasikan pengetahuan teknik (strategis) dan pengetahuan lokal (praktis) untuk saling pertukaran pengalaman dan pengetahuan serta menemukenali kebutuhan perempuan. Kombinasi pengetahuan ini menghasilkan pengetahuan emansipatoris yaitu pengetahuan yang membebaskan, ide yang lebih bisa diterima oleh pengurus dan peserta yang menggerakan pada tindakan pemberdayaan masyarakat. 


\section{DAFTAR PUSTAKA}

Daulay, H. (2006). “ Pemberdayaan Perempuan (Studi Kasus Pedagang Jamu Di gedung Johor Medan)". Jurnal Harmoni Sosial. Medan, Sumatera Utara, Indonesia: Universitas Sumatera Utara.

Dyah, R., \& Hastuti.(t.th.). Model Pemberdayaan Perempuan Miskin Berbasis Pemanfaatan Sumber Daya Pedesaan. Fakultas Ilmu Sosial Eknomi, UNY.

Fauzi, I. (2013, Agustus 22).surabaya.tribunnews.com. Retrieved Mei 25, 2015, from http://surabaya.tribunnews.com/2013/08/22/ sekolah-perempuan-desa-ini-ada-di-kota-batu: http:// surabaya.tribunnews.com/2013/08/22/sekolah-perempuandesa-ini-ada-di-kota-batumpel.

Habermas, J. (1987). The Theory of Communicative Action, Vol 2, Lifeworld and System: A Critique of Fungsionalist Reason. Boston: Beacon Press.

Hustedde, R. J. (2009). Seven Theories for Seven Community Developers. In R. Philips, \& R. H. Pittman, An Introduction to Community Development (p. 28). USA: Roudledge.

Kenny, S. (2010). Developing Community for the Future. Victoria: Australia.

Muttalib, J. A. (1993). Menggunakan Kerangka Pemampuan Wanita: Bahan Pelatihan Jender dan Pembangunan. Jakarta: Kantor Menteri Negara UPW.

Novian, B. (2010, Oktober 22).http://kelurahanpondokbambu.com. Retrieved Mei 6, 2015, from http://kelurahanpondokbambu. com: http://kelurahanpondokbambu.com/index. php?option $=$ com_content $\&$ view $=$ article $\&$ id $=117 \% 3$ Asekilas tentang-pemberdayaan-perempuan\&catid=38\%3Apkk\&Item $\mathrm{id}=57 \&$ lang $=$ in 
Tindakan Komunikatif dalam Model Pemberdayaan Wanita Pada Sekolah_

Salim, A. (2011). Teori dan Paradigma dalam Penelitian Sosial. Yogyakarta: Tiara Wacana.

\section{Wawancara}

Ibu Hana, Hasil wawancara tanggal 26 September 2015, pukul 10.30 - 13.00 .

Ibu Rina, Hasil wawancara tanggal 26 September 2015, pukul 10.30 $-13.00$

Ibu Anta, Hasil Focused Group Discussion (FGD) tanggal 03 Oktober 2015, pukul 14.00 - 15.30) 
Halaman ini bukan sengaja untuk dikosongkan 